\title{
Effects of the Spudcan Penetration on the Adjacent Foundations
}

\author{
Yongren R. Wu*, Xiaobing Lu and Xuhui Zhang
}

Institutive of Mechanics, Chinese Academy of Sciences, Beijing, China

\begin{abstract}
To study the effects of spudcan penetration on the adjacent foundations of offshore platforms, experiments and numerical simulations (using business software ABAQUS) are carried out. It is shown that the penetration of spudcan can cause the soil layer affected in an annular zone. The affected zone has a maximum width of one times the diameter of the spudcan. The deflection of the platform's foundation increases with the penetration of spudcan. The smaller the density of soil layer is, the bigger the displacement of the foundation is. However, the maximum displacement at the top of the foundation changes little once the penetration depth is over a critical value. The bigger the diameter and the penetration depth of the spudcan are, the bigger the displacements of the foundation are.
\end{abstract}

Keywords: Spudcan, saturated fine sand, platform's foundation.

\section{INTRODUCTION}

Jack-up rigs are used extensively in offshore engineering to drill oil and gas wells or used to work-overs on a fixed jacket installation. Depending on the jacket footprint and the positioning of the jack-up rig, the spudcans may be close to the permanent piled foundations of the jacket. It will result in stressing of the piles due to the lateral deformations caused by the penetration of the spudcan. The bearing capacity of the soil layer may be affected as well. Therefore, the effects of the spudcan penetration on the pile or bucket foundation of platform should be considered [1]. The degree of moment restraint applied at the bottom of the leg by the soil to the spudcan is quite uncertain due to the unknown effects of the soil-structure interaction between the spudcan and the sand in seabed $[2,3]$.

Efforts have been put into the soil-structure interactions by many researchers $[4,5]$. However, it is difficult to obtain the exact solution of this problem because of the complexity [6-8]. The key issue in determining the effects of spudcan penetration on the piles is the soil-spudcan and soil-pile interaction.

The effects of spud-can penetration on the foundations of fixed platforms are studied first by experiments. Then, numerical simulation is carried out based on the experimental results. The effects of factors, such as the density of soil layer, the penetration depth and the penetration velocity of spudcan, are investigated.

\section{DIMENSIONAL ANALYSIS}

First, dimensional analysis is carried out to obtain the main factors and simplify the experimental and numerical simulations $[9,10]$. In this problem, the main independent variables are as follows (Fig. 1): parameters of pile foundation: the depth $L_{p}$, the diameter $R_{p}$, the density $\rho_{p}$, the

*Address correspondence to this author at the Institutive of Mechanics, Chinese Academy of Sciences, Beijing, China; Tel: 861082544192;

E-mail: xbinlu@ sohu.com stiffness of anti-bending $E I$, Poisson's ratio $v_{p}$ and the load $P_{p}\left(P_{p x}, P_{p y}\right.$ are the sum of the self-gravity of the platform and the applied load in the $x$ and $y$ directions, respectively). The spudcan is assumed to be a rigid body and with a diameter of $R_{c}$ and a height of $D_{d}$. The soil layer's parameters: the elastic modulus $E_{s}$, the poisson's ratio $v_{s}$, the Cohesion $C$, the internal friction angle $\varphi_{s}$, the density $\rho_{s}$. The distance between the foundation and the spudcan $L_{p c}$. The friction angle between the spudcan and the soil layer $\varphi_{s c}$. The penetration velocity $v$. The other parameters are the gravity acceleration $g$. The unknowns are the deflection of the foundation $L_{h}$. Considering $\rho_{g} g R_{c}^{5} /(E I)<<1$, the dimensionless form of the relation between the unknowns and the variables can be expressed as follows:

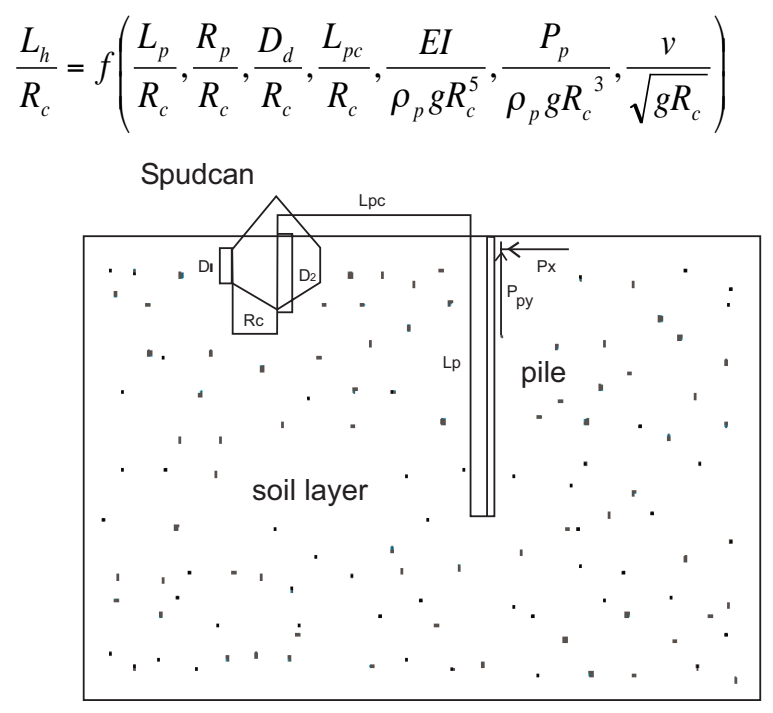

Fig. (1). Sketch of spud-can penetration. 

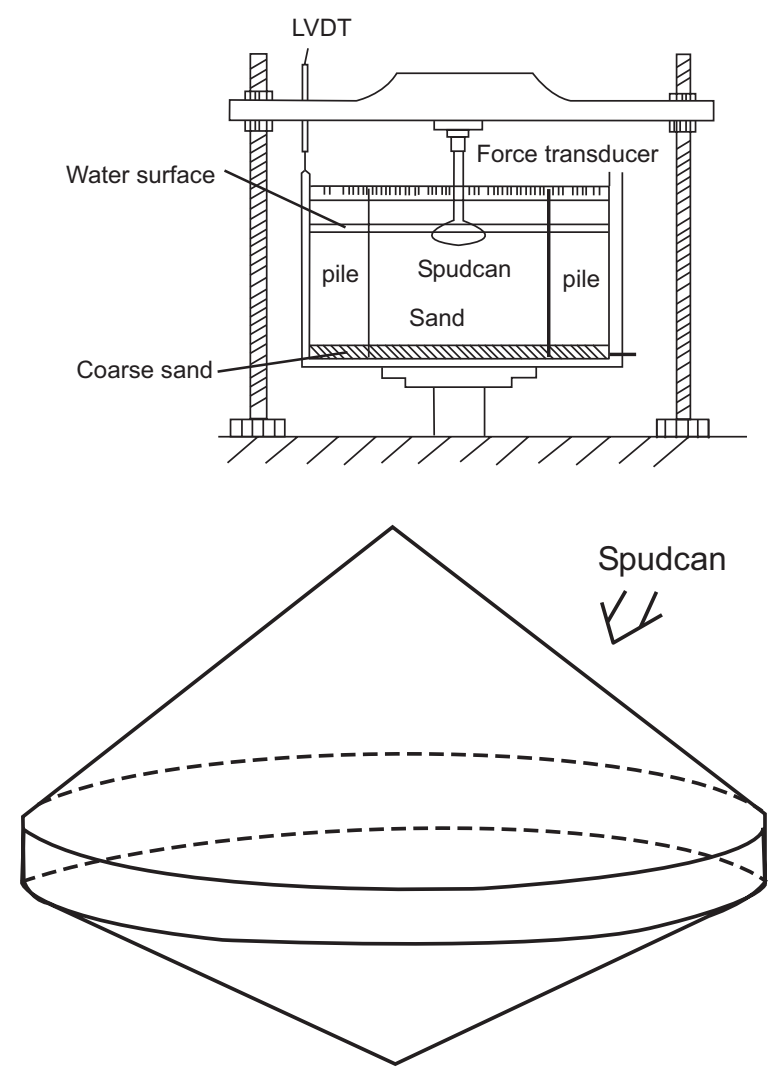

Fig. (2). Layout of the model.

\section{EXPERIMENTAL PROCEDURES AND RESULTS}

\section{The Layout and Procedures of Experiments}

Experiments are carried out in an organic glasses box with a size of $50 \mathrm{~cm} \times 50 \mathrm{~cm} \times 50 \mathrm{~cm}$. The spudcan is penetrated from the center of the box (Fig. 2). The soil layer is constituted of fine sand with a special gravity 2.69 , average grains diameter (D50) $0.014 \mathrm{~cm}$ and permeability coefficient $1 \times 10^{-}$ ${ }^{4} \mathrm{~cm} / \mathrm{s}$. After the dry sand sample has been prepared, the sand layer is saturated by filling water from the bottom of the tank through a valve. A $2 \mathrm{~cm}$ thick coarse sand layer is laid at the bottom of the box to allow the water to rise uniformly and prevent the piping. When the water level is $1 \mathrm{~cm}$ over the sand layer surface, apply vacuum in the sand for 38 hours to increase the saturation degree. The saturation degree is about $98 \%$ in tests, which is tested by measurement of the pore pressure. The saturation degree is the ratio of the pore pressure divided by that in full saturation condition.

Two LVDTs are used to measure the penetration depth of the spudcan and the deflection of the pile, respectively. When the penetration depth is over a given value, the load is stopped. The design of experiments is shown in Table $\mathbf{1}$.

(The position of the pile is the ratio of the distance between the center of sand layer and the side of spudcan to the diameter of spudcan).

\section{Reliability of Experiments}

To validate the reliability of experiments, repeated experiments are carried out first. Fig. (3) shows the development of the deflection on the pile's top with the penetration of spudcan. It is shown that the results in 6 experiments are all agreement well.

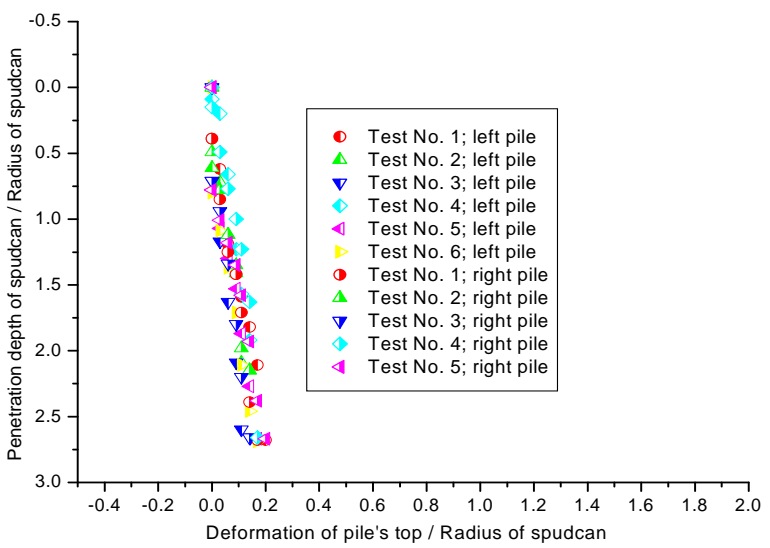

Fig. (3). Deformation at pile's top in six repeated experiments.

Table 1. Experimental Conditions

\begin{tabular}{|c|c|c|c|c|c|}
\hline No. & $\begin{array}{c}\text { Dry Density of Sand } \\
\left(\mathbf{g} / \mathbf{c m}^{-3}\right)\end{array}$ & $\begin{array}{c}\text { Diameter of Spudcan } \\
(\mathbf{c m})\end{array}$ & $\begin{array}{c}\text { Penetration Velocity } \\
(\mathbf{m m} / \mathbf{m i n})\end{array}$ & $\begin{array}{c}\text { Position of the Left } \\
\text { Pile }\end{array}$ & Position of Right Pile \\
\hline \hline $1 \sim 5$ & 1.6 & 7 & 2 & 1 & 1 \\
\hline 6 & 1.6 & 7 & 2 & 1 & 1.5 \\
\hline 7 & 1.5 & 7 & 2 & 1 & 1.5 \\
\hline 8 & 1.7 & 7 & 2 & 1 & 1.5 \\
\hline 9 & 1.6 & 12.5 & 4 & 1 & 1.5 \\
\hline 10 & 1.6 & 12.5 & 6 & 1.5 \\
\hline 11 & 1.6 & 12.5 & 8 & 1 \\
\hline
\end{tabular}




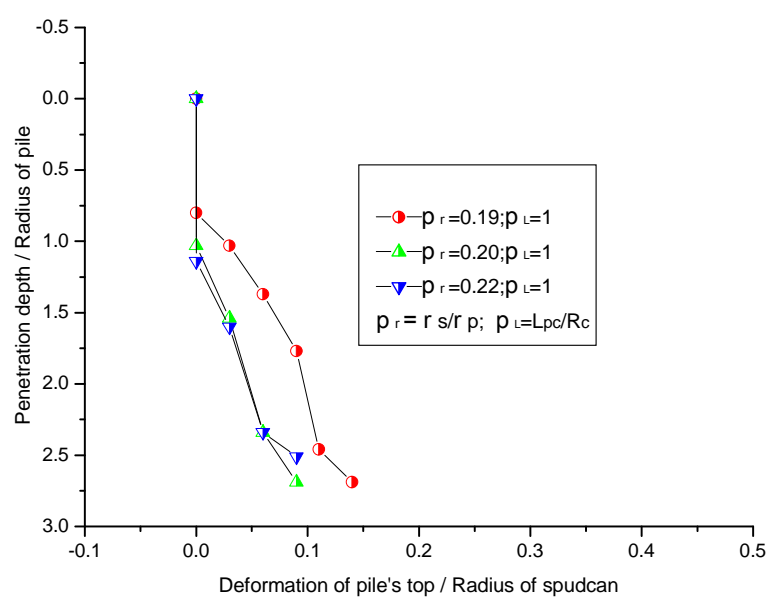

Fig. (4). Effect of soil density on the deflections on the pile's top.

\section{Effects of Factors on the Displacement on the Top of the Foundation}

\section{Effects of the Soil's Density and the Pile's Position}

The effects of the soil's density and the pile's position on the horizontal deflections on the pile' top are investigated by changing the parameters $\pi_{\rho}\left(=\rho_{\mathrm{s}} / \rho_{\mathrm{p}}\right)$ and $\pi_{i}\left(=L_{p c} / R_{c}\right)$. Fig. (4) and Fig. (5) show the relation of dimensionless parameter $L_{h} / R_{c}$ (the deflection on the top of pile is divided by the diameter of spudcan) and $\mathrm{D}_{\mathrm{d}} / \mathrm{R}_{\mathrm{c}}$ (the penetration depth is divided by the diameter of spudcan). It is shown that the smaller $L_{h} / R_{c}$ is, the bigger $L_{p c} / R_{c}$ is. The deflection on the pile' top increases with the increase of the penetration depth and with the decrease of the soil's density and the distance between the spudcan and the pile foundation. When the distance between the spudcan's side and the pile foundation is over one times of the spudcan's radius, the displacement of pile's top may be neglected.

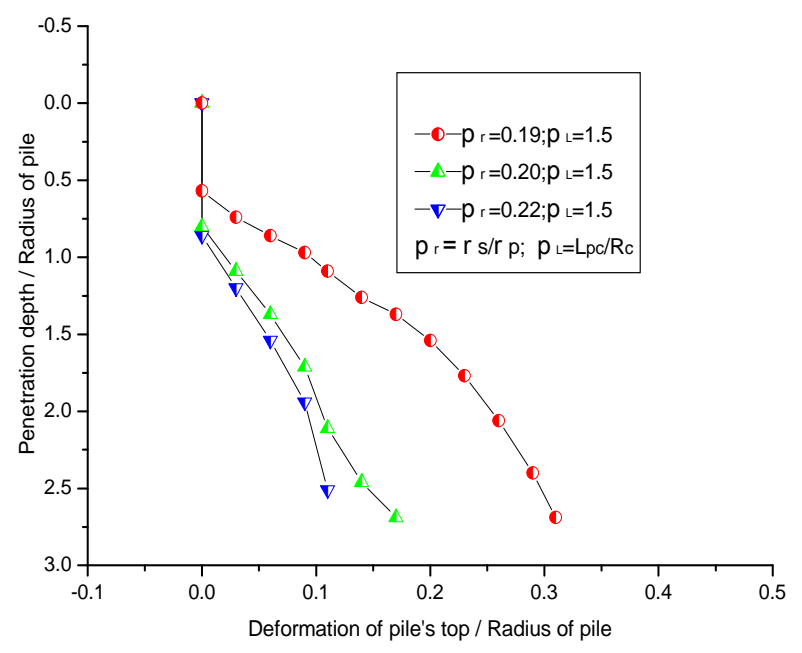

Fig. (5). Soil density vs deformation at pile's top $\left(L_{p c} / R_{c}=1.0\right)$.

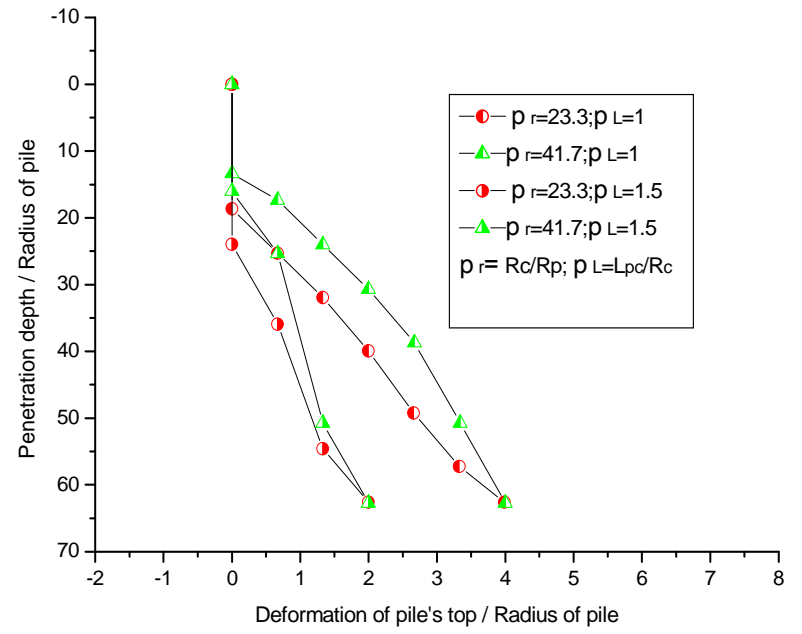

Fig. (6). Spud-can radius vs deformation at pile's top $\left(L_{p c} / R_{c}=1.5\right)$.

\section{Effects of Spudcan's Radius}

The effects of spudcan's radius are investigated by changing the dimensionless parameter $R_{c} / R_{p}$ (Fig. 6). It is shown that the changes of $R_{c} / R_{p}$ have small effects on the maximum displacement. The displacements on the top of pile are mainly formed at the first stage with the increase of $R_{c} / R_{p}$. When the spudcan's penetration depth is over some critical value, the deflection of the pile decreases. The bigger the dimensionless parameter $L_{p c} / R_{c}$ is, the smaller the dimensionless parameter $L_{h} / R_{c}$ is. That means, the deflection of the pile decreases with the increase of the distance between the spudcan and the foundation.

\section{Effects of the Penetration Velocity of the Spudcan}

The effects of the penetration velocity of the spudcan is investigated by changing the dimensionless parameter $v / \sqrt{g R_{c}}$. Figs. (7 and 8) show the relation between $L_{h} / R_{p}$ and $D_{d} / R_{p}$ under different dimensionless penetration velocity $v / \sqrt{g R_{c}}$ and different distances between the spudcan and the pile $L_{p c} / R_{c}$. It is shown that the effects of $v / \sqrt{g R_{c}}$ are obvious on the process of pile foundation's displacements but not on the maximum. When the penetration velocity is big, the displacement develops fast. Otherwise, the maximum displacement occurs only when the spudcan is penetrated into some depth. The slope of the settlement zone caused by the penetration of spudcan ranges from $28^{\circ}$ to $31^{\circ}$ (Table 3). The sketch of the settlement zone is shown in Fig. (9). The diameter of the settlement zone is about two times the diameter of spudcan.

Although it increases obviously under the spudcan, the density of the soil changes little in the other zones. The den- 
Table 2. Soil Densities After Experiments

\begin{tabular}{|c|c|c|c|c|c|}
\hline $\begin{array}{c}\text { Penetration Velocity of } \\
\text { Spudcan } \\
(\mathbf{c m} / \mathbf{m i n})\end{array}$ & $\begin{array}{c}\text { Slope Angle of } \\
\text { Settlement } \\
\text { Zone }\end{array}$ & $\begin{array}{c}\text { Density of Soil } \\
\text { Under Spudcan } \\
\left(\mathbf{g} / \mathbf{c m}^{-3}\right)\end{array}$ & $\begin{array}{c}\text { Density of Soil Sur- } \\
\text { rounding the Settle- } \\
\text { ment Zone } \\
\left(\mathbf{g} / \mathbf{c m}^{-3}\right)\end{array}$ & $\begin{array}{c}\text { Density of Soil at the } \\
\text { Upper Part Sur- } \\
\text { rounding the Spucan } \\
\left(\mathbf{g} / \mathbf{c m}^{-3}\right)\end{array}$ & $\begin{array}{c}\text { Density of Soil at the } \\
\text { Lower Part Sur- } \\
\text { rounding the Spucan } \\
\left(\mathbf{g} / \mathbf{c m}^{-3}\right)\end{array}$ \\
\hline \hline 0.2 & $29.4^{\circ}$ & 1.74 & 1.61 & 1.62 & 1.58 \\
\hline 0.4 & $28.4^{\circ}$ & 1.77 & 1.6 & 1.63 & 1.67 \\
\hline 0.6 & $28.6^{\circ}$ & 1.68 & 1.58 & 1.58 & 1.67 \\
\hline 0.8 & $30.9^{\circ}$ & 1.65 & 1.6 & 1.67 \\
\hline
\end{tabular}

Table 3. Parameters of Soil Layer

\begin{tabular}{|c|c|c|c|c|c|}
\hline & $\begin{array}{c}\text { Modul us E } \\
\mathbf{1 0}{ }^{5} \mathbf{P a}\end{array}$ & Poisson's Ratio v & $\begin{array}{c}\text { Cohesion C } \\
\text { Pa }\end{array}$ & $\begin{array}{c}\text { Internal Friction } \\
\text { Angle } \phi\end{array}$ & $\begin{array}{c}\text { Floating Density } \\
\text { g/cm }\end{array}$ \\
\hline \hline Zone I & 5 & 0.25 & 5000 & 23 & 0.692 \\
\hline Zone II & 5 & 0.25 & 5000 & 23 & 0.692 \\
\hline Zone III & 5 & 0.25 & & & 0.692 \\
\hline $\begin{array}{c}\text { Zone below the } \\
\text { spudcan }\end{array}$ & 6 & 0.2 & & \\
\hline
\end{tabular}

sity of the soil under the spudcan increases with the decrease of penetration velocity (Table 2 ).

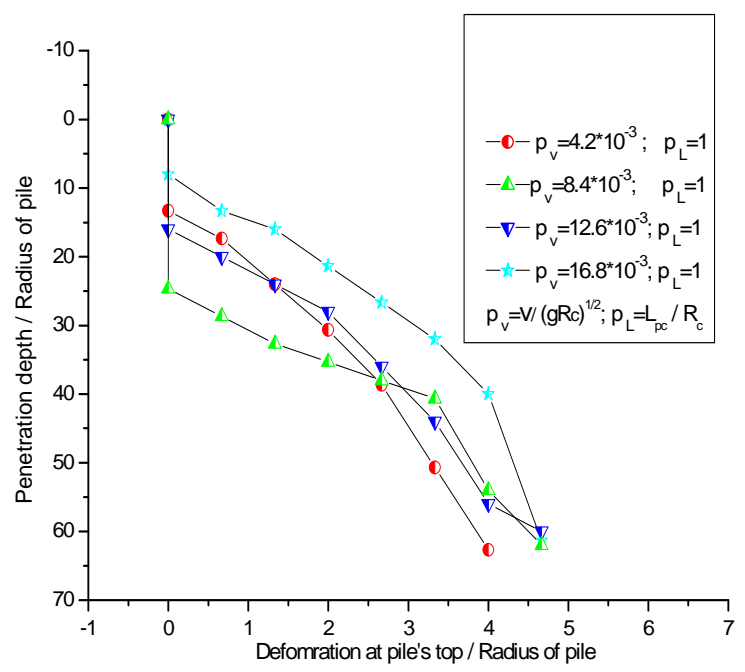

Fig. (7). Deformation at the pile's top vs. penetration velocities $\left(L_{p c} / R_{c}=1.0\right)$.

\section{NUMERICAL SIMULATION}

Business software ABAQUS are used here to simulate the effects of the spudcan penetration on the pile foundation of fixed platforms. Firstly, the numerical results are compared with the centrifugal experimental results to certify the constitutive relation and the numerical net model used in computing. Secondly, effects of the spudcan's penetration on the pile's stresses, deformation and the deformation of the

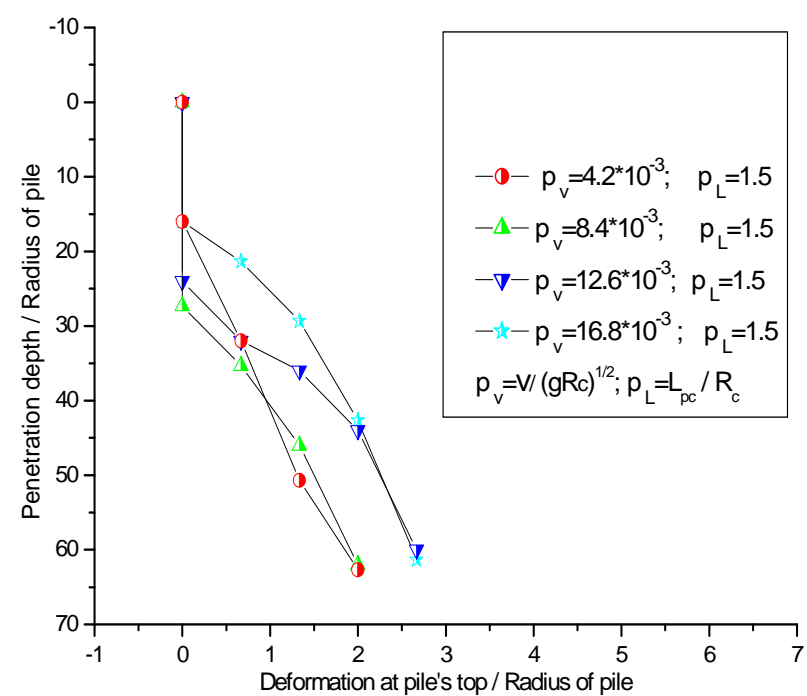

Fig. (8). Deformation at pile's top vs. penetration velocities $\left(L_{p c} / R_{c}=1.5\right)$.

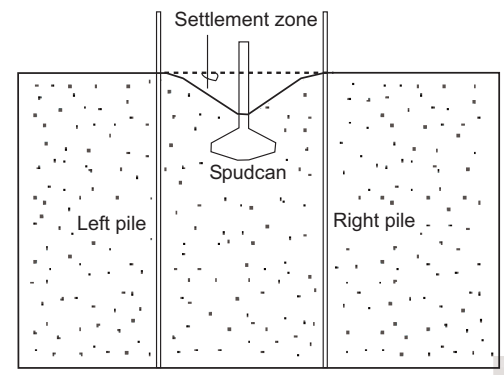

Fig. (9). Soil surface position after experimenting. 
soil layer surrounding the pile foundation are investigated. It is shown that the soil layer is affected obviously inner the zone which is one times the spudcan's diameter away from the side of the spudcan.

\section{Numerical Model}

To validate the numerical model, the numerical results are compared with the centrifugal experimental results. The parameters adopted in numerical computing are all obtained from literatures [6,7]. The scale of soil layer is length $\times$ width $\times$ height $=5000 \mathrm{~cm} \times 5000 \mathrm{~cm} \times 2600 \mathrm{~cm}$. The soil layer is divided into three parts: the zone I which the spudcan is penetrated into, the damaged zone II and elastic zone III (Fig. 10). Zone I is a cylinder with a radius of $5 \mathrm{~m}$. Zone II is an annular strip with a width of $10 \mathrm{~m}$. The other is zone III. The pile foundation is located at the position one times of the spudcan's radius away from the spudcan's side.

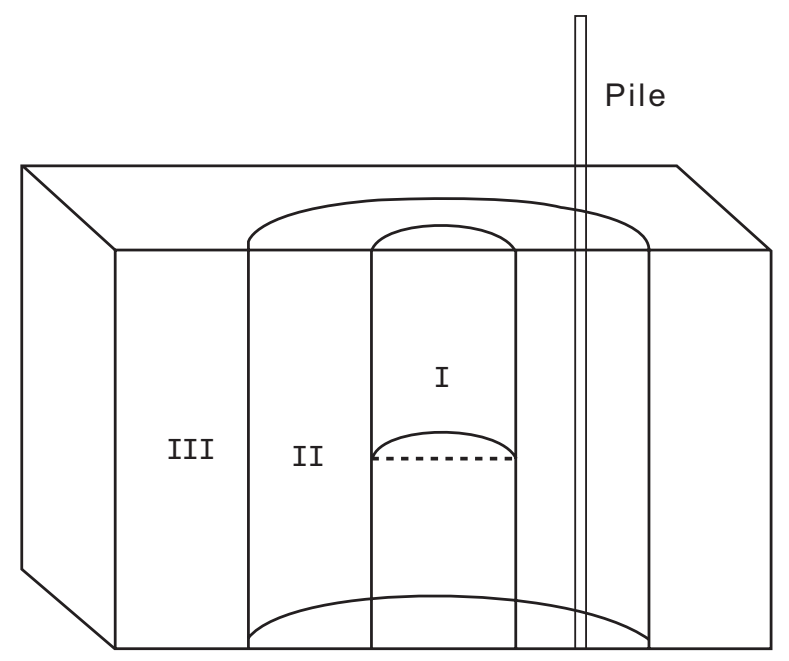

Fig. (10). Sketch of numerical model.

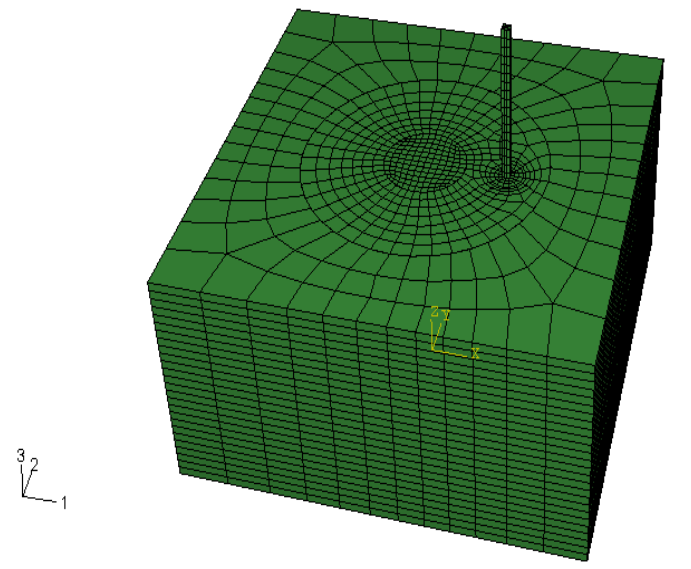

Fig. (11). Sketch of the Network.

\section{Network and Boundary Conditions and Initial Condi- tions}

The network is shown in Fig. (11). The pile foundation is tied with the soil layer. That means, the foundation and the soil layer have the same displacement. To guarantee the precision of numerical simulation, the network is densified cision of numerical simulation, the network is densified near the foundation and spudcan.

The bottom is fixed, e.g. $u_{x}=0, u_{y}=0, u_{z}=0$. The surface is free. The normal fixed conditions are adopted in other boundaries. The initial earth stresses are applied before the penetration of spudcan.

\section{The Constitutive Relation}

The model of Mohr-Coulomb is used in Zone I and II. The linear elastic model is used in zone III. The parameters of constitutive relation are shown in Table 3 .

\section{Comparison of the Numerical and Experimental Results}

The comparison of the numerical and centrifugal experimental results is shown in Fig. (12). It is shown that the numerical and experimental results are agreement well with each other, except at the zone near the bottom. The reason of error is that the convergence of numerical simulation is difficult when the penetration depth is over some value because the kaoline soil is very soft. The adopted constitutive relation causes error at the condition of big deformation.

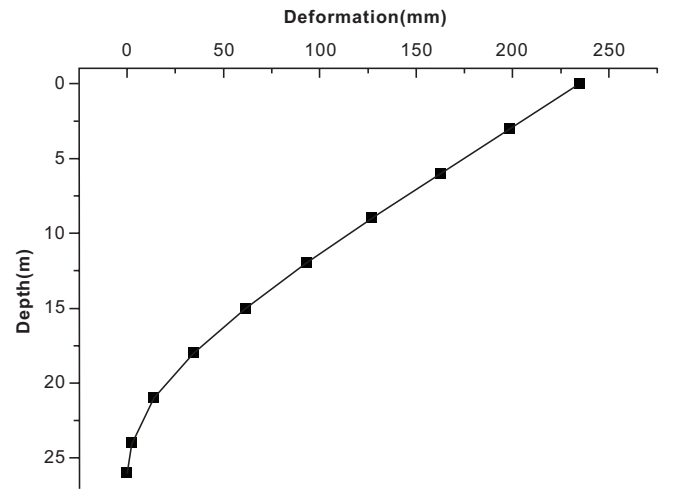

a) Deflection of pile when the penetration depth is $14 \mathrm{~m}$

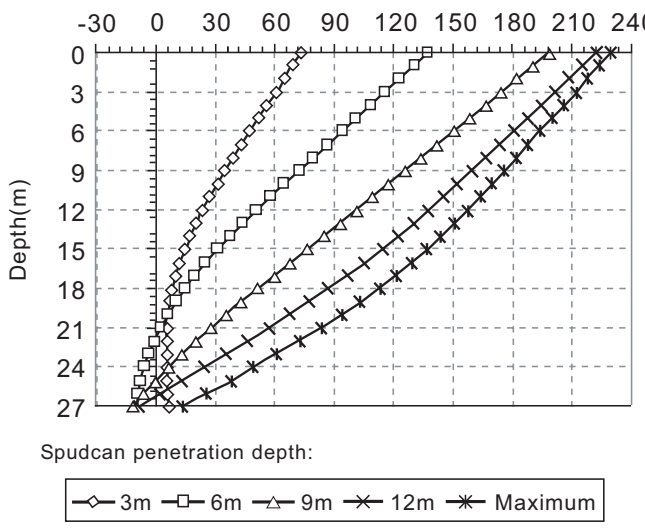

b) Deflection of pile at different penetration depth in experimental results

Fig. (12). Comparison of the lateral deformation of piles.

\section{Numerical Results}

Fig. (13) shows the stresses distribution of the soil layer and the pile foundation. Because it has a big elastic modulus and is tied with soil layer in simulation model, the pile foundation bears most of the load. Thus a narrow zone with small stress surrounding the pile occurs. The spudcan penetration causes the soil below moves laterally. The stresses distribu- 
tion is shown in Fig. (14). It is shown that the movement of soil induces the pile foundation bend laterally. There exists stress concentration at the end of the pile foundation.

The distribution of the horizontal displacements of soil layer at the face of $y=0$ is shown in Fig. (15). It is shown that the distribution of displacements at the left and right sides of the spudcan are not symmetrical.

Fig. (16) shows the vertical displacements at the surface of soil layer. It is shown that the pile foundation limits the lateral movement of the soil at the right side in some extent. The displacements of the soil at the left side of the spudcan are big and the isoline of horizontal displacements distributes uniform. Fig. 17(a-d) shown the settlement at different depth. Fig. (17a) shows the vertical displacements of the soil layer at $6 \mathrm{~m}$ depth. It is shown that the vertical displacements are smaller than that at the surface. Fig. (17d) shows the vertical displacements of soil layer at $24 \mathrm{~m}$ depth. The maximum displacement at this depth is only $0.08 \mathrm{~m}$

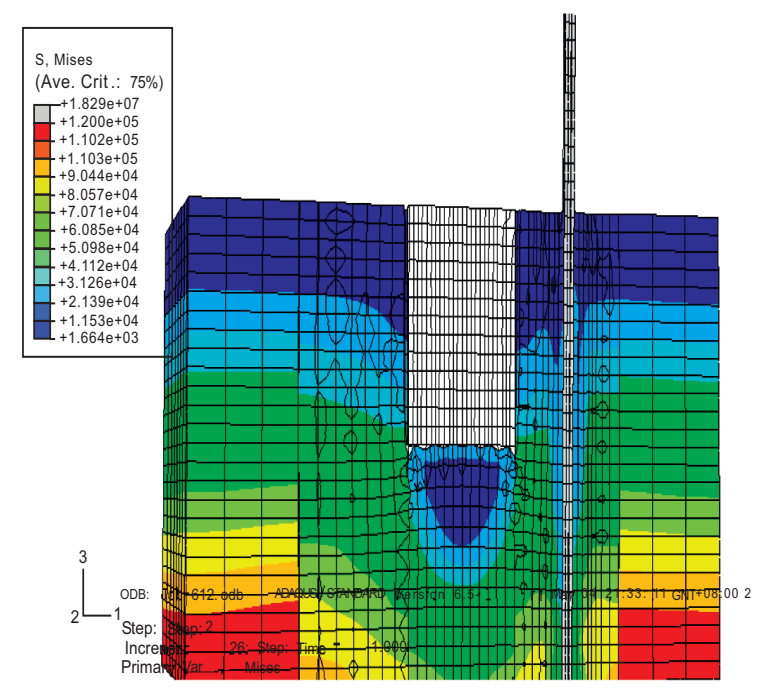

Fig. (13). Stress distribution at $\mathrm{y}=0$.

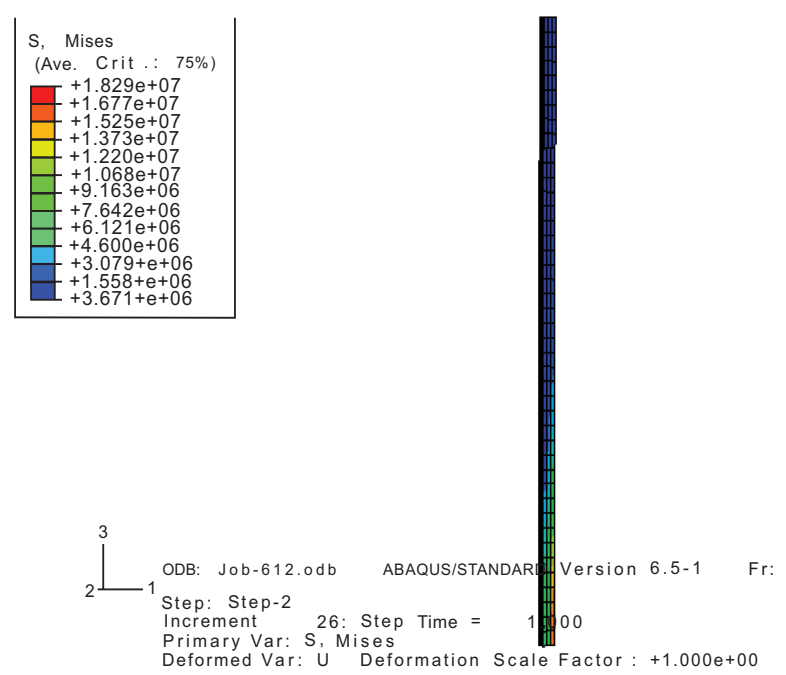

Fig. (14). Stress distribution of the pile.

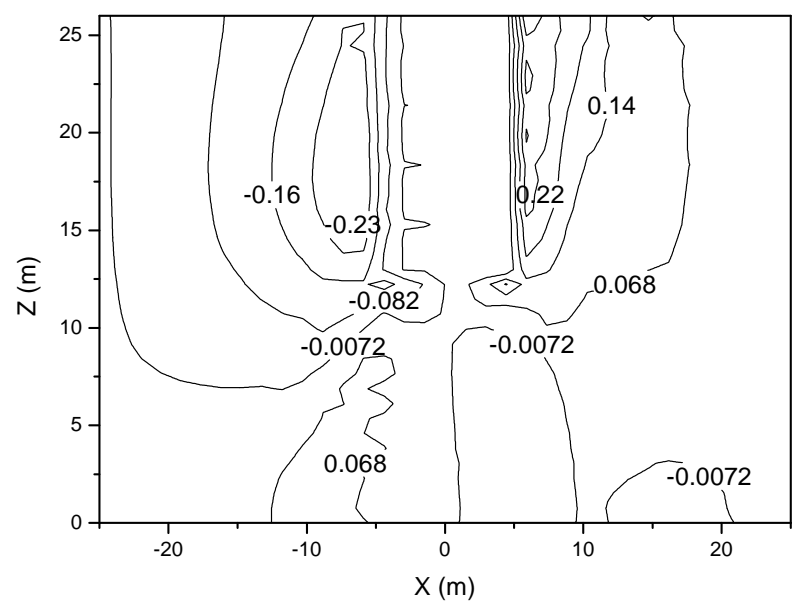

Fig. (15). Horizontal displacement of the soil layer at $y=0$.

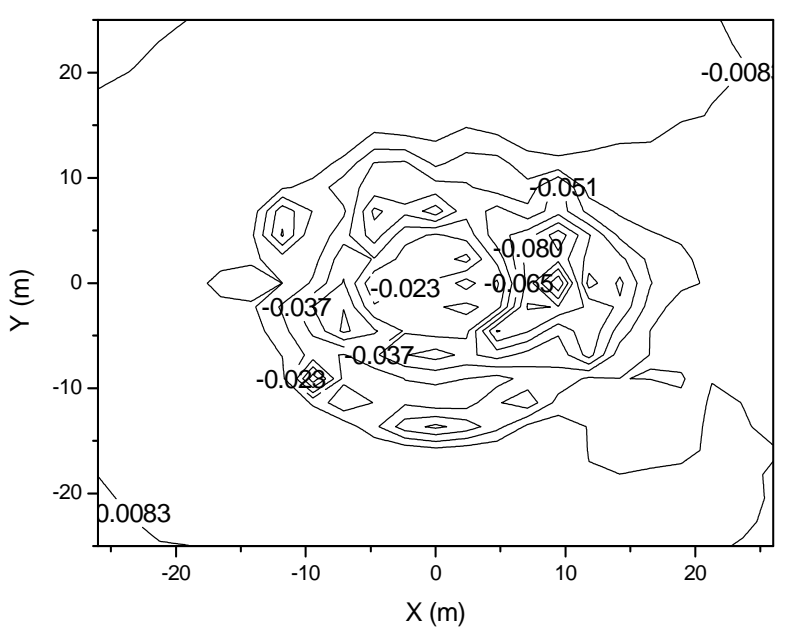

Fig. (16). Vertical displacement at the surface of the soil layer.

\section{CONCLUSIONS}

A series of experiments and numerical simulations are carried out to investigate the effects of spudcan's penetration on the adjacent pile foundations. It is shown that the effects of penetration depth, soil's density, distance between the spudcan and the pile foundation are obvious. The diameter of the settlement zone is about two times the diameter of the spudcan. The slope of the settlement zone caused by the penetration of spudcan ranges from $28^{\circ}$ to $31^{\circ}$ which is close to the internal friction angle of fine sand used in experiments. The density of soils under the spudcan increases obviously. The displacement of the pile foundation decreases with the increase of the distance between the spudcan and the pile foundation and with the decrease of diameter of the spudcan. The effects of the ratio of spudcan's diameter to pile's diameter and the penetration velocity are little on the maximum displacement of the pile but are obvious on the process. 


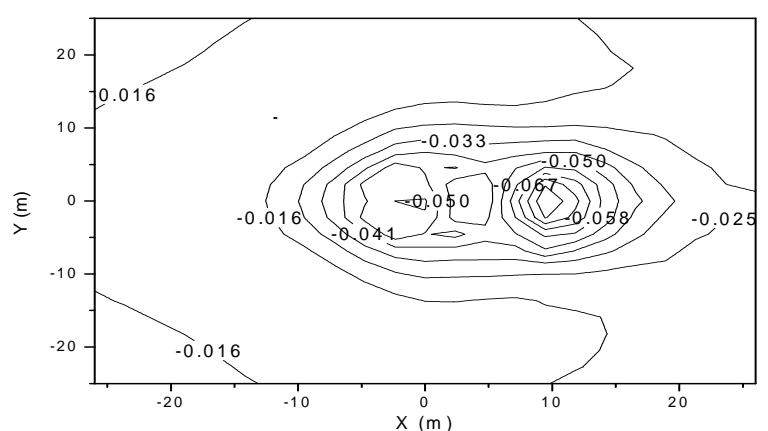

(a) $6 \mathrm{~m}$

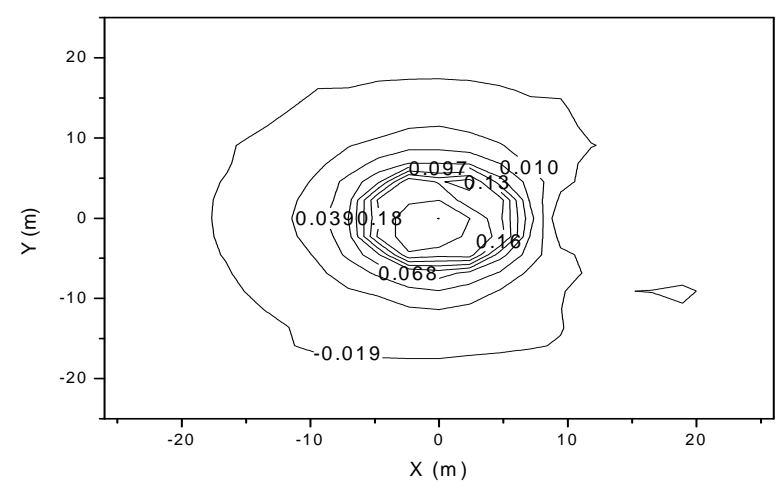

(b) $13 \mathrm{~m}$

Fig. (17). Vertical displacement distribution at different depths.

\section{ACKNOWLEDGEMENTS}

This program is supported by the fund of Chinese Ocean Oil Co. and Chinese Academy of Sciences"_KJCX2-SWL03-01"(40025103) and National Natural Science Fund (No. 10772182).

\section{REFERENCES}

[1] X.M. Tan, J.Y. Guo, and C. Lu, "Effect of spudcan penetration on neighboring existing pile," In: Proc. $16^{\text {th }}$ Int. Offshore and Polar Engrg. Conf., San Francisco, California: USA, June 2006, pp. 516523.

[2] M.J. Cassidy, "Non-linear analysis of jack-up structures subjected to random waves," Ph. D Thesis, University of Oxford, 1999.

[3] C.N. Springett, R.W.P. Stonor and W. Xu, "Results of a jack-up measurement programme in the North Sea and their comparison with the structure analysis," Marine Struct., vol. 9, pp. 53-70, 1996.

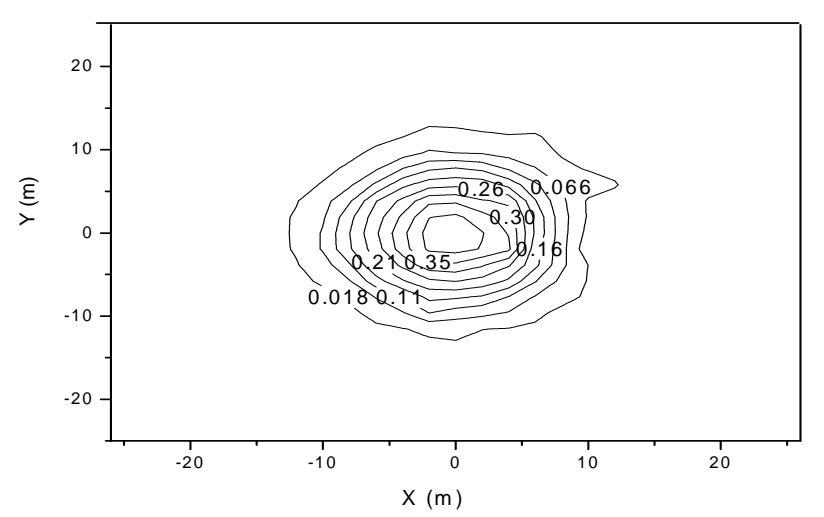

(c) $19 \mathrm{~m}$

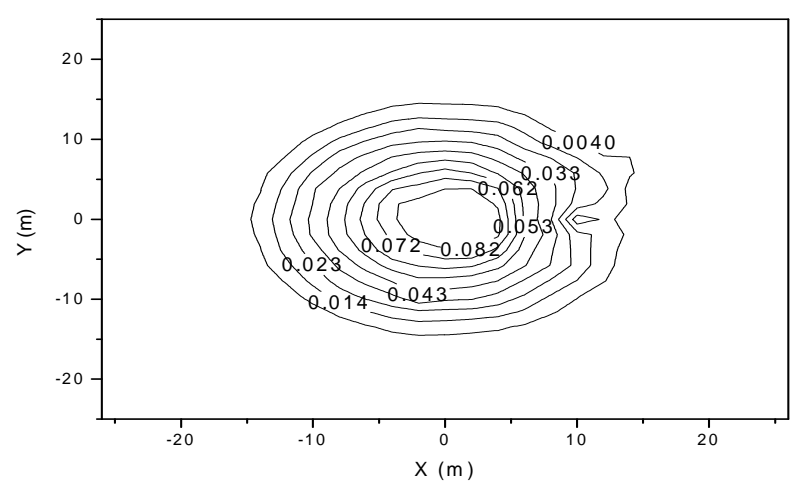

(d) $24 \mathrm{~m}$

[4] M. Boulon, "Basic features of soil structure interface behavior," Comput. Geotech., vol. 7, pp. 115-131, 1989.

[5] Y.E. Mostafa, and M.H.E. Naggar, "Response of fixed offshore platforms to wave and current loading including soil-structure interaction," Soil Dyn. Earthquake Eng., vol. 24, pp. 357-368, 2004.

[6] H. Y. Ding, J. H. Liu, and C. Zhang, "Analysis of effects of the drawing of spudcan on the cylinder foundation by FEM," China Offshore Oil Gas, vol. 16, pp. 353-356, 2004.

[7] R.J. Siciliano, J.M. Hamilton, J.D. Murff, and R. Phillips, "Effect of jackup spud cans on piles," In: Proc. $22^{\text {nd }}$ Ann. Offshore Technol. Conf. OTC6467, Houston, Texas, pp. 381-390, 1990.

[8] Y. Xie, C. F. Leung, and Y. K. Chow, "Effects of spudcan penetration on adjacent pile, "In: Proc. Int. Conf. Phys. Model. Geotech., Hong Kong, August 2006, vol. 1, pp. 701-706, 2006.

[9] L. I. Sedov, "Similarity and Dimensional Methods in Mechanics (Trans.)," London: Infosearch, 1959.

[10] Q.M. Tan, "Dimensional Analysis," Press. Chin. Univ. Sci. Technol., Hefei: China, 2005.

() Wu et al.; Licensee Bentham Open.

This is an open access article licensed under the terms of the Creative Commons Attribution Non-Commercial License (http://creativecommons.org/licenses/by-nc/3.0/) which permits unrestricted, non-commercial use, distribution and reproduction in any medium, provided the work is properly cited. 